\title{
EARLY CONTACT AND BREASTFEEDING: MEANINGS AND EXPERIENCES ${ }^{1}$
}

\author{
Eloana Ferreira D'Artibale², Luciana Olga Bercini ${ }^{3}$
}

\footnotetext{
${ }^{1}$ Article extracted from the dissertation - O contato e a amamentação precoces no contexto de um Hospital Amigo da Criança, developed in the Nursing Graduate Program (PSE) of the State University of Maringá (UEM), 2012.

${ }^{2}$ Master in Nursing. Paraná, Brazil. E-mail: eloana_dartibale@hotmail.com

${ }^{3}$ Ph.D. in Ecology of Continental Aquatic Environemnts. Professor of the Nursing Department and the PSE/UEM. Paraná, Brazil. E-mail: lobercini@uem.br
}

\begin{abstract}
The aim of this study was to analyze the meanings and experiences of early contact and breastfeeding of the postpartum women admitted at a Baby-Friendly Hospital. It is a descriptive, exploratory study, with qualitative approach, that was developed in a teaching hospital in the Northwest of Paraná state between November 2011 and January 2012, involving the participation of 16 postpartum women. Data were collected by means of non-participant systematic observation of the childbirths and semi-structured interview. The data collected were analyzed using the thematic content analysis. The results revealed that, soon after childbirth, the child-mother binomial provided the woman with a unique experience, triggering various sensations into the bio-psycho-social-cultural context of each one of the mothers, with feelings and meanings that favored the mother-child bond and the outset of breastfeeding.

DESCRIPTORS: Mother-child relations. Breast feeding. Humanization of assistance. Nursing.
\end{abstract}

\section{O CONTATO E A AMAMENTAÇÃO PRECOCES: SIGNIFICADOS E VIVÊNCIAS}

RESUMO: O estudo tem como objetivo analisar os significados e as vivências do contato e da amamentação precoces de puérperas internadas em um Hospital Amigo da Criança. Trata-se de um estudo descritivo, exploratório, com abordagem qualitativa, que foi desenvolvido em um hospital universitário da Região Noroeste do Paraná, de novembro de 2011 a janeiro de 2012, com a participação de 16 puérperas. A coleta de dados foi realizada por meio da observação sistemática não participante dos partos, anotações em diário de campo e entrevista semiestruturada. O tratamento dos dados foi realizado por intermédio da análise de conteúdo e modalidade temática. Os resultados revelaram que a aproximação entre o binômio mãe-filho logo após o nascimento proporcionou uma experiência única à mulher, desencadeando sensações diversas dentro do contexto biopsicossociocultural de cada uma delas, com sentimentos e significados favoráveis ao vínculo mãe-filho e ao início da amamentação.

DESCRITORES: Interação mãe-filho. Aleitamento materno. Humanização da assistência. Enfermagem.

\section{EL CONTACTO Y AMAMANTAMIENTO PRECOCES: SIGNIFICADOS Y EXPERIENCIAS}

RESUMEN: Este estudio tiene como objetivo analizar los significados y las experiencias del contacto y amamantamiento precoces de las puérperas internadas en un Hospital Amigo del Niño. Se trata de un estudio descriptivo, exploratorio, con abordaje cualitativo, que se desarrolló en un hospital universitario en el Noroeste de Paraná, de noviembre de 2011 a enero de 2012, con la participación de 16 puérperas. Los datos fueron colectados por medio de la observación sistemática no participante de los partos, apuntes en diario de campo y entrevista semiestructurada. El tratamiento de los datos fue realizado por medio del análisis de contenido, modalidad temática. Los resultados revelaron que el acercamiento entre el binomio madre-hijo, en seguida al nacimiento, proporcionó una experiencia única a la mujer, desencadenando diversas sensaciones dentro del contexto biopsicosociocultural de cada una de ellas, con sentimientos y significados favorables al vínculo madre-hijo y al inicio de la amamantación.

DESCRIPTORES: Relaciones madre-hijo. Lactancia materna. Humanización de la atención. Enfermería. 


\section{INTRODUCTION}

Aiming at enhancing the indexes and benefits of Breastfeeding (BF), the World Health Organization (WHO) and the United Nations Children's Fund (UNICEF) idealized the BabyFriendly Hospital Initiative (BFHI), in 1990. The initiative was implemented in Brazil in $1992^{1}$ and has become a relevant element in supporting $\mathrm{BF}$ actions. Child-Friendly Hospitals (CFH) have doubled exclusive breastfeeding indexes in the child's first days of life compared with other hospitals that did not comply with the initiative. ${ }^{2}$

Hospitals accredited as Child-Friendly are expected to meet minimum global criteria settled by the BFHI, WHO and UNICEF, presented in the Ten Steps to Successful Breastfeeding. It is worth highlighting the fourth step - "help mothers initiate breastfeeding within a half-hour of birth" - as in the revised, updated and broadened interpretation toward a comprehensive care the practice evolved to "place babies in skin-to-skin contact with their mothers immediately following birth for at least an hour and encourage mothers to recognize when their babies are ready to breastfeed, offering help if needed."1:40

This practice provides the newborn (NB) with sensorial stimuli produced by the touch, smell and sounds that contribute to the motherchild interaction and greater chance of success in the breastfeeding process. The skin-to-skin relation generates feelings of happiness, love, tranquility and comfort to both the mother and the baby. The smell promotes the familiarization with the scent of both the mother and the breast milk, making it easier for the baby to grasp the nipple and thus contributing to the onset of $\mathrm{BF}$. The hearing is stimulated by the mother's low frequency heartbeats and voice, providing the baby with enhanced emotional security. ${ }^{3-4}$

In this sense, the stimulus and the establishment of such bond enable the humanization of the mother-child care, thus complying with the recommendations of the Humanization of Prenatal and Birth Program (HPBP) and the Rede Cegonha, which advocate that both the mother and the baby must be offered effective care practices grounded on scientific evidences and humanization principles, and that both individuals are guaranteed to stay in close relationship throughout the whole hospital stay, starting at the delivery moment, and have skin-to-skin contact and breastfeeding support in the first hour of birth, if possible, among other actions that qualify this care practice and favor mother-child health promotion. ${ }^{5-6}$

The humanization of the obstetric and neonatal care is the major condition to the delivery and postpartum follow-up, as it involves the adoption of beneficial measures and procedures toward following up the delivery and the birth, thus preventing unnecessary and traditionally performed interventions, that favor neither the mother nor the NB and often provoke enhanced risks for both. ${ }^{5}$

In several institutions, the BFHI is still being implemented and adapted. The practice of the fourth step is not always carried out as it is recommended; skin-to-skin contact and breastfeeding are often stimulated, but they do not occur right after the delivery.

Although the benefits of skin-to-sin contact following the delivery are much more effective in comparison with having the baby wrapped up in cloths or already dressed with baby's clothes for the contact with the mother, the latter is also quite significant and valuable for the mother-child relationship whenever it is done immediately after the delivery. ${ }^{7}$

Therefore, this primary interaction following delivery, despite not being the recommended skinto-skin contact, stands out as the first adaptation phase toward a more humanized care and also as the implementation of the fourth step of the BFHI. The change of traditional practices is still a great challenge to the organization of the work and to the practice of healthcare professionals. ${ }^{3}$

In this manner, taking into account the relevance of early skin-to-skin contact and breastfeeding, the aim of this study was to assess the meanings and experiences arising from early contact and breastfeeding in postpartum women admitted in a BFH, as such understanding can lead to the establishment and/or consolidation of the fourth step of the BFHI, as well as the awareness of healthcare professionals involved in the motherchild care on the importance of such practice.

The guiding question of this study is: "what are the experiences and meanings of the early contact and breastfeeding for mothers who had their babies within a BFH context?"

\section{METHODOLOGY}

This descriptive, exploratory study with qualitative approach makes circumscribed social 
descriptions possible and is aimed to explore particular issues of the subjects involved. ${ }^{8}$

The study was performed at the Gynecology and Obstetrics (GO) unit of a teaching hospital $(\mathrm{TH})$ in the Northwestern region of the state of Paraná, Brazil, in the period between November 2011 and January 2012. The selected subjects were women aged 18 or over admitted at the hospital for the delivery process and who were able to both breastfeed and make contact with their babies right after birth, and who were transferred to the rooming-in ward (RW) of the TH's GO Clinic, our research field. The selection of participants also depended on the delivery conditions of the NB. The baby should present clinical conditions that did not contraindicate the contact and breastfeeding immediately after delivery.

Although the study did not report any exclusion of participants at the delivery process, as the research had already been carried out, all newborns were in adequate clinical conditions, showing weight, gestational age and Apgar score within normal standards, thus causing them to be able to establish contact and breastfeed, according to the results presented in this study.

The number of participants in the study was not predetermined, as the amount of individuals was defined by the reach of the study's objectives, considering that the validation of the participation of subjects is defined by the potential each participant had to empirically carry out the object of the study in all of its dimensions. It should be highlighted that the qualitative search causes the researcher to worry less about the generalization and more about the broadness, reach and diversity of the comprehension process of the group to be assessed. ${ }^{8}$ In this sense, 16 women took part in the study.

Data were collected by means of non-participant systematic observation of the childbirths, which were properly noted down in the field diary, thus promoting a clear understanding of the reality from which this present study evolved. The research also carried out a semi-structured interview that took place after the delivery, respecting the women's recovery period.

The interview occurred in a calm location offered to patients by the institution during their stay. The site was located out of the institution, near the maternity ward, so that the privacy of the subjects could be preserved. Only two interviews were carried out in the RW, in agreement with the preference of the postpartum women.
The interpretation of the data produced by the interviews was analyzed using the thematic content analysis, which was divided in three stages: pre-analysis, examination of the material and handling of results, and inference and interpretation. $^{9}$

Aiming to guarantee the anonymity of the women, and in order not to nominate them in a generic way (subject 1 , subject 2 , etc), the study decided to address them under the names of precious or semi-precious stones, as these women, the assessed moment and the obtained testimonies were quite precious in the construction of this research, allowing us to access the personal experience of each woman and providing a rich collection of knowledge and experiences that led us to learn the human realities endowed with unique meanings and significances, essential features toward the construction and consolidation of a more humanized care.

The study complied with the guidelines proposed by Resolution 196/96 of the National Health Council and was approved by the Human Research Ethics Committee of the State University of Maringá, under protocol number 509/2009.

\section{RESULTS AND DISCUSSION}

The participants were aged between 18 and 34 years, with a mean of 26.06 . Their educational degree was significantly heterogeneous, as the group was made of several women who had not completed elementary school and one who was taking a university degree. Five women had completed high school and six had not concluded it. As per their marital status, only two participants did not have a partner, namely a widowed and a single woman.

Regarding their occupation, five women were seamstresses, three were factory production assistants, and the others were as follows: a textile factory assistant, a kitchen maid, an administrative assistant, a seller, an electronic process instructor, a hairdresser, a housekeeper, and a financial assistant.

The majority of the women (11) had a delivery history prior to the delivery approached by the research. All of them showed gestational age between 37 and 40 weeks, with a mean of 39.06 weeks, thus characterizing due NBs.

As per the deliveries, ten were normal and the remainder was cesarean section. The cesarean section was seen as the factor that most interfered 
in the postponement of the contact and the first breastfeeding process. A similar finding was identified in a cross-sectional study carried out in Rio de Janeiro, where the procedure was found to reduce in half the prevalence of breastfeeding in the first hour in all 47 assessed maternity wards. ${ }^{10}$

All NBs displayed satisfactory birth conditions and showed a favorable status for the early contact and breastfeeding, as they weighed over 2,500 grams at birth, varying from 2,690 to 4,040 grams; Apgar between 6 and 10 in the first minute; and Apgar between 9 and 10 in the fifth minute. The NB that displayed Apgar 6 in the first minute only needed a tactile stimulus, so that in the fifth minute he could have Apgar 10, that is, able to the contact and breastfeeding.

The observation of the routine developed at the institution showed that the approached hospital, in spite of being a BFH and complying with the BFHI norms, still presents a radically rooted technicist care in some situations. The routine also recommended that professionals should prioritize immediate care toward the newborn right after delivery, even in situations when the baby did not display an immediate need for care.

All deliveries received support both from the nursing team and the medical team. Right after the delivery, the NB is routinely received by the obstetrician, then forwarded to the pediatrician and the nursing team. These professionals provide immediate care to the NB right at the Surgical Center (SC), the location where deliveries take place.

In this context, in the majority of cases (14), the contact and breastfeeding occurred when the NB had already been cared for by the teams, being then brought to the mother wrapped in blankets and cloths. In only two cases, the NBs were handed naked to the postpartum women, right after delivery. Nevertheless, this was quite a quick contact that lasted less than a minute in one event and one whole minute in the other.

Hence, it was clear that the fourth step was not literally met, as recommended by the BFHI. Nonetheless, it is worth highlighting that the contact and the breastfeeding processes took place in all cases within the so-called "sensitive" period, comprehended by the two first post-delivery hours. This moment is deemed to be an ideal time for the breastfeeding to start, as the NB is much more sensitive to tactile, thermal and odor-based stimuli, and the catecholamine levels are high, thus causing the NB to be kept active and facilitating his search for the mother's nipple in order to more easily initiate the breastfeeding process. ${ }^{11}$

The time lapse between the delivery and the beginning of the physical contact varied from 0 to 99 minutes, and the time lapse between the delivery and the first breastfeeding/beginning of the first suction process varied from 8 to 99 minutes. In six cases there was no breastfeeding/suction within the first hour after birth, the minimum period recommended by the BFHI for the motherchild contact to be continued, a time to stimulate and support the BF process.

The aforementioned information helps us concisely locate the major characteristics regarding the context and the participants in the study. These data stand out as relevant input, as they constitute the basis on which the meanings and experiences were built by the women.

Taking into account that the care services rendered to the woman throughout the labor and the delivery processes can interfere both in the BF process and in the way the mother will take care of the baby ${ }^{12}$, it is important to emphasize the significance and the consequences of the compliance with the fourth step of the BFHI for these women, as well as the factors associated with it.

In this sense, based on the thematic analysis of the women's testimonies and the notes in the field diary, three categories were identified, as follows.

\section{Building knowledge on early contact and breastfeeding}

This research showed that the majority of participants (15) referred to have carried out prenatal programs and an adequate number of consultations. Crystal was the only one who did not attend the full program recommended by the Ministry of Health (MH), as she only had five consultations. The $\mathrm{MH}$ orients women to carry out at least six consultations in the prenatal period, preferably one in the first quarter, two in the second quarter and three in the last quarter. ${ }^{13}$

Despite the adequate follow-up, the majority of the women (13) affirmed not to have been educated on the early contact and breastfeeding in those occasions, not even in the care service provided prior to the delivery, thus pointing out communication and healthcare deficits, which stand out as a negative factor for the establishment of such practices. 
Among the interviewees who reported not to have received any orientation, two women indicated that they already had a certain degree of knowledge on the practice as a result of previous experiences and access to information resulting from different means of communication.

Well, I watched it on television, I saw it at the healthcare units, in brochures, but not during the prenatal program (Crystal).

No, but as I have already had one child here, I already figured out the way it would be carried out (Dolomite).

In view of such reality, women were surprised when the healthcare team initiated the contact and the breastfeeding right after the delivery.

[...] It was weird when I got to the room and the nurse reached out to my breast and said, "we will bring your baby to breastfeed". That was sort of strange, but it was nice (Amethyst).

Wow, it was quite exciting, because I thought they would not hand me the baby, I thought they would take him to the nursery ward to be cleaned up. I was wrong, because the baby was brought straight to me. So, it was...wow! Unexpected, it was very nice! (Apatite).

The three women who affirmed to have been educated regarding the early contact and breastfeeding processes reported very superficially on these orientations, showing to have low degree of information on the issue. One of these women showed to be more aware of the practice; in addition to the higher educational level, she mentioned that the acquired knowledge was provided in the prenatal period as a result of her own inquiries and curiosity.

[...] In the prenatal period I used to ask even more questions. They did not bring the information to me, I was very curious and started finding things out, I began to prepare myself for the best process possible. Thank God, it was all right! (Sapphire).

Therefore, it can be clearly seen that this reality generates a lack of preparation of the women to the early contact and breastfeeding practices, thus compromising the establishment and benefits of such actions. If that moment is not carried out and experienced in its fullness, its positive results and benefits will not be fully explored either.

Bearing these facts in mind, the construction and the establishment of nursing interventions, above all educational and care-based ones, during the prenatal period, pre-delivery and even in the delivery room, are an extremely important step to aid and make women aware of the relevance and the right they have to enjoy the early contact and $\mathrm{BF}$ practices.

The health education practice promotes the development of a critical and reflexive conscience of individuals, generating conscientious choices regarding how their health is conducted and offering a mutual exchange of knowledge and experiences that are able to empower the patient, the professional and the institution. ${ }^{14-15}$

It is up to healthcare professionals who follow these women up during the prenatal and the delivery periods to provide them with scientific theoretical support, as well as to follow up, support and guide them in the time of the delivery, as this moment stands out as an all-embracing emotional and physical event in which physiologic, social, cultural and psychological aspects are intertwined, thus generating a strong need for a qualified, specific care toward the woman and her demands. ${ }^{16,22,24}$

Amongst the healthcare professionals involved in the time of delivery, the nursing team plays quite a special role due to its steady and direct participation in the care service and followup of the mother and the child throughout and after the delivery.

The attitudes of the healthcare professional, such as integration and acknowledgement of the woman, the child and the companion, are capable of facilitating the operationalization of the fourth step, once they are grounded on the humanization principles and everyone involved in the care service is embraced and treated with respect. ${ }^{16}$

\section{Understanding feelings and meanings of the early contact and breastfeeding}

Whenever the woman is granted the opportunity of seeing, touching, taking and breastfeeding her baby, this moment represents the apex of the long time she had to wait throughout the pregnancy. ${ }^{17}$ The feelings expressed by the subjects concerning the first contact between mother and child evidenced that this first integration was overwhelmingly emotional, providing plenty of excitement, with a sense of happiness by seeing the baby right there, a time to check out if everything is alright and to be able to touch him/her.

To be able to touch the baby right after the delivery is wonderful! (Agatha).

[...] the woman is thrilled in seeing the baby and holds him tight. Holding the NB on her arms, the flabbergasted postpartum woman lovingly touches him, 
kisses his forehead and fascinatedly says, "you are so beautiful"! (Notes in the field diary - Domolite).

Amidst a whirlwind of feelings, when asked about the meaning of the early contact and breastfeeding, the women find it very difficult to express proper words, as it can be seen below.

I do not know how to explain it [utter silence] (Fluorite).

I do not know what to tell you. I really don't know. I think I was amazed, it was so much love! (Apatite).

What can I say? How could I... [she silenced and became thoughtful, quit expressing herself] (Opal).

The majority of participants were very straightforward concerning the meaning of this moment. The justification for such a terse expression was reported in only three testimonies, in which they affirmed to find it quite hard to describe something so permeated with countless meanings and emotions.

This is, literally, the natural contact. It is quite difficult to translate it into words. It looks like a...well... how can I tell you? [laughs] It is the divine expression of the nature of men and the nature of divinity. It's a magical thing, this is all I have to say! It's magical, it's absurdly magical! (Jade)

Uh, what it meant? Well, I don't even have the words for it. I just can't find a meaning for it. It is all for ourselves! It's quite an amazing thing! (Turquoise)

Such singular experience causes the woman to redirect her attention from the discomfort and pain produced by the delivery to the pleasure of holding her baby. After the baby is delivered, the woman finds herself open to new experiences related to the interaction with the newborn. ${ }^{17}$ Hence, despite the suffering she undergoes, the reward arises from the encounter yearned for so long, as expressed in the following testimony: oh, it meant... well, in spite of all the suffering, it was quite worth it in the end (Ruby).

Although these experiences encompass other subjects in this scenario, the leading character in the delivery process and in the first encounter with the baby is the woman, who experiences a unique and remarkable event full of very singular meanings. The extrauterine relationship of each mother-child pair has a sui generis quality, in which each child has quite a proper way to develop communication with the mother and vice-versa. ${ }^{18}$ This singular relationship can be observed in the following testimony: that little thing is yours [...]
You think, well, this baby is mine, he has my blood, he has my characteristics, he was inside of me, he will love me, I will be his mother. Then, right there, you realize that: he is mine! We have something no one will ever feel, belonging only to both of us, an intimate thing that only belongs to us. When you take him in your arms... oh dear Lord! (Sapphire)

In this sense, the comprehension of the meaning and the feelings generated by the early contact and breastfeeding, even in the delivery room, implies the respect for the desire, the culture and the social support of each woman admitted at the delivery ward in order to finish the gestational process and to be forwarded to an immediate birth. ${ }^{19}$

\section{Triggering early breastfeeding: advantages and dispositions}

The BF stands out as a crucial factor toward the promotion and protection of the child's health. Scientific studies provide evidence that the breast milk stands out as an ideal food to NBs, as it offers all necessary nutrients, in adequate quantity and quality, thus providing the child with an increasingly healthy development. Additionally, the breastfeeding practice plays a relevant role in the immunological system by strengthening the body functions against infections and other common diseases in childhood, thus influencing the reduction of neonatal mortality rates. ${ }^{20-21}$

In view of these scientific evidences and the several measures promoted by health services aimed to encourage $\mathrm{BF}$, women have become much more aware of the benefits the breast milk brings to the child. Such fact can be observed in the interviewees' testimonies following the question on their perception of the relevance of breastfeeding.

It means everything, or else... the breast milk is something originated in us and it's quite healthy. We know that it does not have any disease, there's no danger, comparing to the other types of milk (Apatite).

Because the baby gains more weight, gets healthier. They say that the first breastfeeding works toward preventing other sorts of diseases. And this is very important! (Opal).

Despite the undisputable relevance of the biological properties of the breast milk, the breastfeeding act also allows for an intimate, deep bond, often being the first contact of the mother with the baby. This connection enables the woman to touch, to get to know her child, to open new pathways for further interactions, causing her to feel 
calmer. Whenever early breastfeeding takes place, the woman's confidence, skill and know-how are enhanced and facilitated toward continuing the breastfeeding practice, thus influencing the trajectory and the history of the mother-child binomial. ${ }^{17}$

In addition to being grounded on biological issues concerning the newborn's well-being, two women affirmed that such attitude greatly contributed to the protection and security of their children.

I think that the best way to show your love for your child is to breastfeed him. It means to protect him (Agatha).

My contact with the baby makes him feel more secure and... the health of the baby, which is totally guaranteed through the mother's milk (Amethyst).

The breastfeeding woman is not only offering her breast milk, she is experiencing a moment that is able to stir pleasant sensations that will deeply impact the affection between the binomial. ${ }^{22}$

Although all participants presented some degree of knowledge regarding the benefits of breastfeeding and pointed out various advantages concerning such practice, it is also important to take into account the women's agreement with the early contact and breastfeeding, as the mother's affective willingness to comply with these practices is essential for the individual's psycho-affective development to take place..$^{23}$

When questioned about their willingness to practice the contact and breastfeeding immediately after the delivery, the majority of women did not refer to any obstacle regarding their disposition and agreement, and this is a clear indication that the stimulus toward the practice of the contact and the BF right after birth is a pertinent issue. Such fact has also been perceived in the non-participant systematic observation.

Good disposition, it was okey, I was fine. Everything was calm, the baby's latch was good and he is suckling naturally (Amethist).

[...] Right after the delivery, the woman showed to be quite exhausted, but in a matter of seconds she was once again alert and receptive to the contact [...]. The woman was quite anxious to see her daughter [...]. Minutes after the delivery, the mother received her daughter [...]. With her NB in her arms, the woman caresses her and stands in a state of awe [...]. At seeing the baby active and using her hands to help the suction, the postpartum woman, alone with her baby in the aisle of the surgery center, pulls down one of the sleeves of her nightdress and starts breastfeeding him [...] (Notes in the field diary - Iolite).
The willingness and the disposition the woman shows to breastfeed are critical issues, as it does not refer to an innate action. The BF process is overloaded with a number of values, in such a way that the woman's disposition to breastfeed should not be seen only as a biological factor, but as an action that is also influenced by psychological and social-cultural aspects. Thus, a few interviewed women add their willingness to breastfeed to the desire and enthusiasm of that special moment.

Although the surgery was causing me so much pain, I was so willing to hold the baby and not let him go anywhere. You just let him go because the pain is excruciating, and then you can't bear it anymore [...] But, I was ready to be there for the rest of the day, all night long, if he wanted to get stuck and keep trying to feed on my breast. I could really stay there, I just did not care (Emerald).

I'm completely willing! Because I know it's very important for the baby. These are his first... there are antibodies there for him, something he needs to grow healthy and fine. Besides, there's also the issue of the human contact, which is fundamental for the establishment of the mother-child relationship. That's it. [laughs] (Jade).

The early successful breastfeeding process is one of the consequences of the contact between mother and child right after the delivery. This contact actually opens the door for the breastfeeding, allowing the NB to more easily latch and initiate the suction and resulting in higher chances of an effective suction and an adequate, continuous breastfeeding. ${ }^{24}$

Taking into account the individuality of each participant and seeking to understand the real meaning and the urgent needs of such experience, it is worth highlighting that, in addition to their clear lack of knowledge on the practice, some women referred to difficulties and discomfort in the moment of the contact resulting from the effects of the anesthetic substances and the great effort demanded in the vaginal delivery. Despite these hardships, the women were quite receptive and anxious for the contact to be established.

I was very tired, but after he is in contact with you, you forget everything, even the tiredness. I think I held him for one hour, half an hour in each breast. I just disconnected from the world and didn't even remember the exhaustion. In the SC I was sort of weary because they were still working on the stitches. So, I was quite insecure of holding him there, I was afraid I could let him fall, because I was totally laid down. But in the breastfeeding time I was quite fine (Sapphire). 
The testimonies show that new care strategies capable of minimizing this discomfort must be designed, in a way to allow the woman to feel embraced, secure and confident to trigger the breastfeeding process, turning that moment into a pleasant time for the binomial. In view of this need, a humanized care on the part of the healthcare professional can really make a difference.

Hence, it is very important and necessary for us to comprehend the meanings and experiences of post partum women concerning the early contact and breastfeeding, as the acknowledgement of their opinions, feelings and needs allows for improved conditions toward the establishment of a comprehensive care based on humanist values that are consistent with the desires and the rights of the binomial.

\section{CONCLUSION}

The meanings and experiences of early contact and breastfeeding are connected to the socialdemographic and obstetric characteristics of the subjects, and also to the professional practices, the educational actions made available at the pre- and intra-hospital services, the mother's knowledge on these practices, interpersonal relationships, search for knowledge on the issues, and physical and emotional conditions of the mother, that is, a wide array of integrated factors demanding specific attention and care.

Within this universe, the participants describe the contact and breastfeeding moment, right after the delivery, as a combination of several different feelings ranging from the surprise and estrangement up to overwhelming feelings and emotions hard to be depicted. Additionally, they show not to be prepared yet to enjoy this moment in its fullness.

The awareness of this reality is a relevant tool toward solving or minimizing the problems arising from this moment experienced by the women. The comprehension of this moment can generate actions that provide relief and well-being to the binomial, as the involved aspects and values assigned to this context from the standpoint of the receivers of such care are acknowledged.

In this sense, the results pointed to the need for implementing health education activities, as the clear lack of knowledge on the early contact and breastfeeding causes women to be submissive to the service and to the professionals, thus compromising the establishment of this interac- tion. In view of this necessity, it is up to health professionals to inform and help them in this special moment when the emergence of the roles of mother and child finally takes place. Effective actions are based not only on knowledge, but also on attitudes.

The mother-child interaction process right after birth provides the woman with a unique experience that unleashes a broad scope of sensations within the bio-psycho-social-cultural context of each one of them, generating favorable feelings and meanings toward the mother-child bond and the beginning of the breastfeeding process.

The benefits concerning the early contact and breastfeeding enlisted throughout this study - the favorable agreement of the woman and the intimate relationship established by these practices between the mother-child binomial - are encouraging toward the consolidation of the fourth step of the BHFI and the establishment of BF. Besides standing out as low cost measures, these practices exert quite a strong impact in the BF process and in the mother-child relationship.

Bearing in mind the methodology and the objective of this study, the research was limited by the fact that the small amount of subjects involved does not allow for any generalization. Nevertheless, it stands out as quite a significant study, adding up knowledge to healthcare professionals and offering reflexive, critical thoughts regarding the early contact and breastfeeding as major human needs related to these facts.

Hence, efforts should be made by healthcare professionals - especially the nursing team professionals, as those who stay longer periods with the patient - toward rethinking concepts and developing a sensitive, integrated care that takes into account the whole singularity translated by this special moment.

\section{REFERENCES}

1. Fundo das Nações Unidas para a Infância/Unicef (BR). Iniciativa Hospital Amigo da Criança: revista, atualizada e ampliada para o cuidado integrado: módulo 1: histórico e implementação. Brasília (DF): MS; 2008.

2. Sampaio PF, Morais CL, Reichenheim ME, Oliveira ASD, Lobato G. Nascer em hospital Amigo da Criança no Rio de Janeiro, Brasil: um fator de proteção ao aleitamento materno? Cad Saude Publica. 2011 Jul; 24(7):1349-61.

3. Carfoot S, Williamson P, Dickson R. A randomized controlled trial in the north of England examining 
the effects of skin-to-skin care on breast feeding. Midwifery. 2005; 21(1):71-9.

4. Porter RH. The biological significance of skin-to-skin contact and maternal odours. Acta paediatr. 2004; 93(12):1560-2.

5. Ministério da Saúde (BR). Humanização do parto: humanização no pré-natal e nascimento. Brasília (DF): MS; 2002.

6. Ministério da Saúde (BR). Secretaria de Atenção à Saúde. Manual prático para implementação da Rede Cegonha. Brasília (DF): MS; 2011.

7. Bystrova K, Ivanova V, Edhborg M, Matthiesen AS, Ransjö-Arvidson AB, Mukhamedrakhimov R, et al. Early contact versus separation: effects on motherinfant interaction one year later. Birth. 2008 Jun; 36(2):97-109.

8. Deslauriers JP, KerisetM. Odelineamento de pesquisa qualitativa. In: Poupart J. A pesquisa qualitativa: enfoques epistemológicos e metodológicos. Rio de janeiro (RJ): Vozes; 2008. p. 127-53.

9. Bardin L. Análise de conteúdo. 1. ed. São Paulo (SP): Edições 70; 2011.

10. Boccolini CS, Carvalho ML, Oliveira MIC, Vasconcellos AGG. Fatores associados à amamentação na primeira hora de vida. Rev Saude Publica. 2011 Fev; 45(1):69-78.

11. Moore ER, Anderson GC. Randomized controlled trial of very early mother-infant skin-to-skin contact and breastfeeding status. J Midwifery Womens Health. 2007 Mar-Abr; 52(2):116-25.

12. Narchi NZ, Fernandes RÁQ, Dias LA, Novais DH. Variáveis que influenciam a manutenção do aleitamento materno exclusivo. Rev Esc Enferm USP. 2009 Mar; 43(1):87-94.

13. Ministério da Saúde (BR). Secretaria de Atenção à Saúde. Departamento de Ações Programáticas Estratégicas. Pré-natal e puerpério: atenção qualificada e humanizada - manual técnico. Brasília (DF): MS; 2005.

14. Joventino ES, Dodt RCM, Araujo TL, Cardoso MVLML, Silva VM, Ximenes LB. Tecnologias de enfermagem para promoção do aleitamento materno: revisão integrativa da literatura. Rev Gauch Enferm. 2011 Mar; 32(1):176-84.

15. Santos RV, Penna CMM. A educação em saúde como estratégia para o cuidado à gestante, puérpera e ao recém-nascido. Texto Contexto Enferm. 2009 Dez; 18(4):652-60.

16. Strapasson MR, Fisher ANC, Bonilha ALL. Amamentação na primeira hora de vida em um hospital privado de Porto Alegre: relato de experiência. Rev Enf UFSM. 2011 1(3):489-96.

17. Barbosa V, Orlandi FS, Dupas G, Beretta MIR, Fabbro MRC. Aleitamento materno na sala de parto: a vivência da puérpera. Rev Cienc Cuid e Saude. 2010 Abr-Jun; 9(2):366-73.

18. Freitas CHB, Ângulo M. Relação mãe-bebê logo após o parto e na amamentação: a identificação projetiva realista, pelos sentimentos e sensações do observador. Rev Cient Psicol Formação. 2006 JanDez; 10(10):83-101.

19. Monteiro JCS, Gomes FA, Nakano AMS. Percepção das mulheres acerca do contato precoce e da amamentação em sala de parto. Acta Paul Enferm. 2006 Out-Dez; 4(19):427-32.

20. Toma TS, Rea MF. Benefícios da amamentação para a saúde da mulher e da criança: um ensaio sobre as evidências. Cad Saúde Publica. 2008; 24(2):235-46.

21. Oliveira AA, Castro SV, Lessa NMV. Aspectos do aleitamento materno. Nutrir Gerais Rev Digital Nut. 2008 Fev-Jul; 2(2):1-18.

22. Araújo OD, Cunha AL, Lustosa LR, Nery IS, Mendonça RCM, Campelo SMA. Aleitamento materno: fatores que levam ao desmame precoce. Rev Bras Enferm. 2008 Jun-Ago; 61(4):488-92.

23. Nóbrega FJ. Vínculo mãe/filho. Rio de Janeiro (RJ): Revinter; 2005.

24. Fundo das Nações Unidas para a Infância/UNICEF (BR). Iniciativa Hospital Amigo da Criança: revista, atualizada e ampliada para o cuidado integrado: modulo 3: promovendo e incentivando a amamentação em um Hospital Amigo da Criança: curso de 20 horas para equipes de maternidade. Brasília (DF), MS; 2009. 